\title{
O príncipe maquiaveliano na era digital
}

DOI: 10.1590/1809-58442018211

Vitor Cei Santos ${ }^{1}$

https://orcid.org/0000-0001-6756-3236

1(Universidade Federal de Rondônia, Campus Porto Velho, Departamento de Línguas Vernáculas. Porto Velho - RO, Brasil)

BITTENCOURT, Maíra. O Príncipe Digital. Curitiba: Appris, 2016.

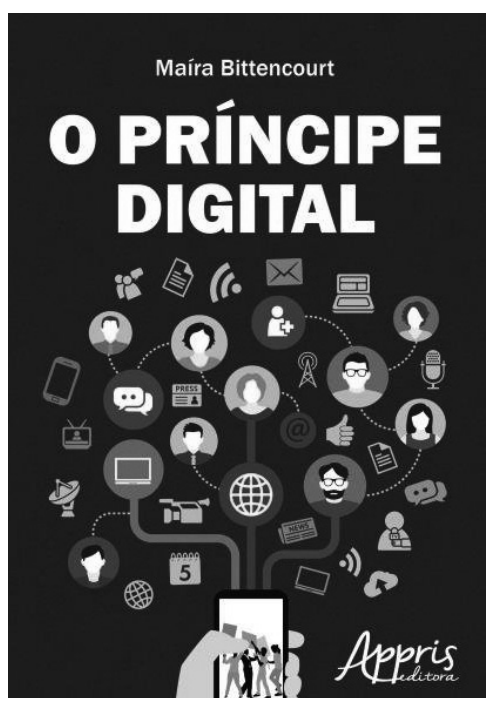

O livro O Príncipe Digital, da jornalista Maíra Bittencourt, professora e chefe do Departamento de Jornalismo da Universidade Federal de Rondônia, campus Vilhena, foi lançado em setembro de 2016, com prefácio do jornalista e professor Eugênio Bucci, orientador da pesquisa apresentada originalmente como tese de doutorado em Ciências da Comunicação na Universidade de São Paulo. O trabalho foi contemplado com o prêmio Tese Destaque USP 2017, conquistando o primeiro lugar na grande área das Ciências Sociais Aplicadas.

O objetivo da obra é ressignificar o conceito filosófico de "Príncipe”, que surgiu com Maquiavel para descrever o governante das monarquias e repúblicas e depois foi apropriado por Gramsci para descrever o partido político como um "Moderno Príncipe”. Dentre outras possíveis releituras do conceito, Bittencourt adotou o “Príncipe Eletrônico” de Octavio Ianni como precursor de seu “Príncipe Digital”.

Se na segunda metade do século XX o rádio e a televisão foram os principais veículos de poder, hegemonia e liderança, exercendo as funções sociais de Príncipe, com o suporte e apoio dos grandes grupos econômicos e políticos, como compreendia Ianni, no século XXI surge um novo Príncipe. De acordo com Bittencourt (2016), o Príncipe Digital não nasce das mídias tradicionais de massa, não precisa ser um intelectual e nem sempre se alinha com os grupos econômicos e políticos hegemônicos. No entanto, ele é tão ou mais influente e eficaz do que as forças tradicionais de poder, hegemonia e liderança.

Os novos líderes de opinião, que podem ser jovens recém-saídos da puberdade como Kim Kataguiri, ou senhores septuagenários como Olavo de Carvalho, passaram a ocupar o 
lugar de liderança que Maquiavel atribuiu ao governante, Gramsci ao intelectual orgânico e Ianni aos porta-vozes dos grandes meios de comunicação. Não obstante, o Príncipe Digital não é encarnado por nenhum indivíduo, como os supracitados, ou organização, como os Movimentos Brasil Livre ou Vem Pra Rua. Segundo Bittencourt (2016), ele é a confluência das categorias principais: Multidão de Anônimos, Líderes de Opinião e Comunidades Virtuais Organizadas, que geram, por meio da Internet e das redes sociais, um processo de Mobilização Social, em conflito ou aliança com os Poderes Políticos e Econômicos Institucionalizados.

A obra é estruturada em sete capítulos que vão se entrelaçando e relacionando os Príncipes, de Maquiavel ao Digital, delineando a liderança, o poder e a hegemonia, descrevendo o cenário virtual e o contexto de ação do Príncipe Digital para, por fim, apresentar suas estratégias de comunicação, avaliando sua influência e eficácia.

Dentre os méritos de O Príncipe Digital, vale destacar a tentativa de oferecer uma fundamentação teórica sobre o príncipe maquiaveliano na era digital com base em pesquisas empíricas de natureza quantitativa e qualitativa. A autora analisou 74 manifestações populares, entre os anos de 2013 e 2015, no Distrito Federal e em 25 estados, de norte a sul do Brasil. Foram 601 entrevistados, respeitando-se a distribuição demográfica indicada pelo Censo do IBGE de 2010. Os questionários com cinco a 20 perguntas foram distribuídos via Facebook, e-mail, Twitter, Linkedin e WhatsApp. Além disso, foram feitas observações sobre 354 Líderes de Opinião, a partir de conteúdos de redes sociais e entrevistas. Assim, à luz de novas práticas, a autora revisita conceitos teóricos.

Apoiando-se em leituras de Maquiavel, Gramsci, Ianni e outros autores, como Malini, Lazarsfeld, Habermas, Hardt e Negri, a autora mantém o rigor teórico, mas não exige que o leitor tenha conhecimento prévio dos autores e livros citados. O estilo do texto é didático, incluindo notas de rodapé com dados biográficos sobre os autores e tabelas com quadros de resumos das principais categorias utilizadas, úteis para leigos e estudantes de graduação, ainda que sejam supérfluas para pesquisadores experientes. Dentre as 29 tabelas, destacamse a $16^{\mathrm{a}}$, com um resumo das cinco fases de manifestações populares do Brasil entre janeiro de 2013 e agosto de 2015, e a 28 , com um resumo do conceito de Príncipe Digital.

Após descrever as características do cenário virtual no qual está inserido o Príncipe Digital, avaliar o seu contexto de ação e o modus operandi de sua comunicação, a autora destaca a influência e eficácia desse novo Príncipe, concluindo que: redes sociais como o Facebook são o principal espaço de Mobilização Social; há alternância constante de Líderes de Opinião, que despertam para tipos específicos de reflexões e organizam o debate; as pessoas de relação pessoal mais íntima exercem mais influência do que os líderes; os Poderes Políticos e Econômicos Institucionalizados tentam influenciar e conduzir a Multidão de Anônimos para que sigam os seus interesses, nem sempre com sucesso; quanto mais os protestos ganhavam legitimação dos partidos políticos e das mídias tradicionais, menor era o engajamento da população nas redes sociais. 
Com o livro O Príncipe Digital, Bittencourt (2016) oferece valiosa contribuição aos esforços por um amplo e inclusivo espaço de debate sobre as atuais problemáticas sociais e políticas que afetam o Brasil, especialmente após a crise política que se intensificou no Brasil depois de junho de 2013. Os sentidos e o legado das manifestações populares e do net-ativismo despertam amplo interesse, não apenas dos especialistas de diferentes áreas do conhecimento que estudam a cultura política contemporânea, mas de todas as pessoas que sentem desconforto intelectual diante do horizonte da atual dinâmica política brasileira.

No atual cenário de múltiplas possibilidades interpretativas, O Príncipe Digital contribui com uma nova interpretação de inegável valor para os estudos sobre Teoria Política Contemporânea, Comunicação Multimídia, Teoria do Jornalismo e Economia Política da Comunicação e da Cultura. Recomenda-se assim, como leitura para todos aqueles que se interessam pela instigante questão do net-ativismo em geral e do legado das jornadas de junho em particular.

\section{Referências}

BITTENCOURT, M. O Príncipe Digital. Curitiba: Appris, 2016.

\section{Vitor Cei Santos}

Doutor em Estudos Literários (área de concentração em Teoria da Literatura e Literatura Comparada) pela Universidade Federal de Minas Gerais, com doutorado sanduíche no Instituto de Estudos Latino-Americanos da Universidade Livre de Berlim. Mestre em Letras pela Universidade Federal do Espírito Santo, com graduação em Filosofia pela mesma instituição e graduação em Comunicação Social (com habilitação em Jornalismo) pelo Centro Universitário Vila Velha. Atualmente é professor do Departamento de Línguas Vernáculas da Universidade Federal de Rondônia (UNIR), campus Porto Velho. Fundou e coordena, desde 2016, o Grupo de Pesquisa (DGP/CNPq) "Ética, Estética e Filosofia da Literatura”. E-mail: vitorcei@gmail.com.

Recebido em: 19.09.2017

Aceito em: 15.04.2018

Este artigo é publicado em acesso aberto (Open Access) sob a licença Creative Commons Attribution Non-Commercial (CC-BY-NC), que permite uso, distribuição e reprodução em qualquer meio, sem restrições, desde que sem fins comerciais e que o trabalho original seja corretamente citado.

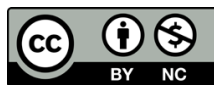

